\title{
PLACES AND NON-PLACES IN MONICA ALI'S BRICK LANE
}

\author{
Julia Goulart Sereno \\ Mestre em Letras - Literaturas de Língua Inglesa - pela Universidade do Estado do Rio \\ de Janeiro (UERJ) \\ julia.sereno@gmail.com
}

\section{RESUMO}

Este artigo objetiva analisar o modo como Nazneen, protagonista do romance Brick Lane (2003), da escritora Monica Ali, recorre às memórias de sua infância em Bangladesh para tentar se distanciar do espaço físico de Brick Lane (a comunidade onde reside em Londres). Usando os conceitos de lugares e não-lugares propostos por Marc Augé (1994), examinarei passagens do romance que caracterizam a sensação de nãopertencimento vivida pela personagem. Através das lembranças e das cartas trocadas com a irmã, Nazneen busca resgatar um lugar de afeto, uma identidade deixada para trás. Porém, o que à primeira vista poderia se caracterizar como uma fuga, é, em essência, uma viagem na busca pelo sentido, pelo pertencimento.

Palavras-chave: diáspora, memória, lugar, não-lugar, pertencimento.

\section{ABSTRACT}

This article aims at analyzing the role of flashbacks experienced by Nazneen, who is the protagonist of the novel Brick Lane (2003), by Monica Ali. By considering the concepts of spaces, places and non-places proposed by anthropologist Marc Augé in Non-Places: Introduction to an Anthropology of Supermodernity (1994), which is mentioned by phi-losopher Zygmunt Bauman in Liquid Modernity (2000), the present article will demonstrate how Nazneen tries to reconstruct/rewrite her spatial and temporal displacement through her memory. However, what could be seen as an escape is, in essence, a journey in search for meaning, for belonging.

Keywords: diaspora, memory, place, nonplace, belonging. 
Brick Lane (2003) tells the story of Nazneen, a Bangladeshi woman who, by means of an arranged marriage with an older man, Chanu Ahmed, moves with him to London, the place where he had made his life for almost twenty years. Living in the small Bangladeshi community of Tower Hamlets with husband and two daughters, Nazneen meets other people who, just like herself, find themselves between the old traditions left behind and the new values that are presented in the English culture. Nazneen often daydreams of the village in which she was born and misses her sister Hasina, who sends her letters from Bangladesh. As Nazneen does not speak English, she feels displaced and alienated from the local cultural aspects. Despite living in a community of immigrants coming from the same region, Nazneen does not feel she belongs to that place, so she falls back on flashbacks of her life in Bangladesh as a way to escape from her painful reality in London. Her flashbacks represent the recovery of a place, of an identity that was left behind.

Also, through exchanging letters to her sister Hasina, Nazneen feels in some way linked to her homeland and memories of her childhood: "Sister I think of you every day and send love. Now you have address you will write and tell all thing about London. It makes me tremble so far away (...) We see each other before long time pass..." (ALI, 2003, p. 18). It is worth quoting James Clifford who points out that "the language of diaspora is increasingly invoked by displaced peoples who feel (maintain, revive, invent) a connection with a prior home" (CLIFFORD, 1994, p. 255). He goes on to argue that diaspora cultures usually live "experiences of separation and entanglement, of living here and remembering/desiring another place" (CLIFFORD, 1994, p. 255). Thus, Nazneen's reading of Hasina's letters is her closest association with what was left behind. Every moment she feels lost, she resorts to her memories as an attempt to find comfort. 
In Non-Places: Introduction to an Anthropology of Supermodernity, French anthropologist Marc Augé (1994) analyzes the relationship between men and space as well as the question involving identity and collectivity. Despite our awareness of the fact that globalization has played a crucial role in the transformation of our world into a place of great social, economic and cultural changes, Augé states that we live in times of production of non-places, which cannot be defined as relational, or historical, or concerned with identity (AUGE, 1994, p. 74). Public places such as airports, subway stations, hotels and supermarkets are examples of non-places, described as alienating spaces, in which we are forced to spend more and more time of our lives. Augé establishes a clear connection between the effects of supermodernity and the occurrence of non-places. Such supermodernity is characterized by excesses, by lack of control and relationship, by the abundance of information and transformations happening at a brisk pace. Another perceptible effect is that people from different cultures have been displaced from their homelands and settled in foreign countries, where they often have to deal with distinct values and cultural practices. Such diasporic processes are marked by a range of motivations, and subjects who have experienced such dislocations often share a feeling of in-betweenness, which can cause either a feeling of not belonging or a gradual process of acceptance of the new home.

Therefore, the specific situation of the immigrant contributes to the formation of multiple identity representations that result from the search for "belonging" and the attempt to recover what Marc Augé claims as the anthropological place. According to him, anthropological studies are interested in the way subjects interpret the category of the "other", giving it a place, a race or an ethnicity. As the notion of belonging extrapolates the physical sphere, the anthropological place is the concrete space that the 
subject claims as being his, which represents his cultural background and is seen as relational, historical and concerned with identity.

Zygmunt Bauman (2000) also refers to the notion of non-places and spaces in Liquid Modernity. The philosopher puts forward that "non-places accept the inevitability of a protracted, sometimes very long sojourn of strangers, (...) to make their presence 'merely physical' while socially little different, preferably indistinguishable altogether..." (BAUMAN, 2000, p. 119). Bauman argues that as differences might be put aside, "they may also be made invisible or, rather, prevented from being seen" (idem, p. 120). It is precisely at this point that he mentions the concept of 'empty spaces', coined by Jerzy Kociatkiewicz and Monika Kostera: "places to which no meaning is ascribed. They do not have to be physically cut off by fences or barriers. They are not prohibited places, but empty spaces, inaccessible because of their invisibility" (BAUMAN, 2000, p. 120). Bauman says empty spaces are devoid of meaning because they are perceived as meaningless or not perceived at all. However, the author agrees that "the emptiness of place is in the eye of the beholder and in the legs or in the car-wheels of the city-goer" (p. 122). A person would feel lost, vulnerable and frightened in those places especially because they do not provide affection or any significant bond.

In literature, various contemporary novels have dealt with the issue of diaspora and the consequent feelings of displacement experienced by immigrants. It is my belief that the notions of non-places and empty spaces shed light on some situations lived by Nazneen in Brick Lane. Therefore, it is important to mention some aspects of the historical and cultural backgrounds of Nazneen's homeland.

Bangladesh is primarily a rural country with most people living outside of the urban areas. The country is mainly bordered by India and its capital Dhaka is one of the biggest 
Muslim cities in the world. The literacy rate in Bangladesh is very low, with significantly higher literacy rates for the male population as compared to women's.

It is estimated that nearly half a million Bangladeshis reside in the UK today, mainly in East London boroughs. In the 1970's, changes in immigration laws encouraged the movement of Bangladeshis to come to the UK and settle there. Brick Lane is located in the London borough of Tower Hamlets, which has one of the highest ethnic minority populations in the capital. Brick Lane used to be a poor Jewish area, but now the region has become the home to Bangladeshis and Pakistanis. On Sundays, the famous Brick Lane Market attracts young people to its Indian sari silks, bagel shops, cheap leather clothes and inexpensive restaurants.

The idea of being part of a local community surrounded by people with the same origin might seem the best choice for an immigrant in a foreign country. However, since the bomb attacks at the London underground in July 2005, Europe has been debating its different integration models for immigrant communities. Young men of Pakistani origin and British nationality were responsible for the bombing, which triggered a strong reaction of British citizens who had supported their country's integration policy so far. According to the Gulbenkian Migrations Forum 2009, the multicultural model adopted by the UK has been facing a crisis. A key issue raised is that European societies might be under threat by immigrants' cultural and religious practices. In the chapter entitled Communities, Bauman addresses the question of similarity and difference:

'We' of the patriotic/nationalist creed means people who are different from us. Not that 'we' are identical in every respect; there are differences between 'us' along side the common features, but the similarities dwarf, defuse and neutralize their impact. (..) And not that 'they' differ from us in every respect; but they differ in one respect 
which is more important than all the others, important enough to preclude a common stand and render genuine solidarity unlikely whatever the similarities that make us alike. (...) the boundaries dividing 'us' from 'them' are clearly drawn and easy to spot, since the certificate of 'belonging' contains just one rubric, and the questionnaire which those applying for the identity card are required to fill in contains but one question and a 'yes or no' answer (BAUMAN, 2000, p. 202).

Considering that most immigrants live in exclusive boroughs, communities or city districts, we might wonder to what extent those enclosed areas make them invisible to the others. They exist as a community, not as individuals. Discrimination and prejudice have been an obstacle for those willing to live or work outside the local communities. Nevertheless, I agree that despite sharing religious and cultural aspects, some immigrants might experience the feeling of not belonging to the situation they are living in.

In Brick Lane, Nazneen represents this conflicting side of a diasporic subject, facing the dilemma of living in a non-place for the reasons mentioned previously in this article. Thus, I will now refer to some passages of the novel that illustrate the strategies used by the protagonist to resist the spatial and temporal displacement as well as to make her present more tolerable.

At first, Nazneen struggles not to question why her life is the way it is. As a Muslim girl, she was taught to accept her Fate without standing in its way. Her mother used to say that fate eventually decided everything, whatever route a person followed. Then, Nazneen does not let herself have wishes because she does not believe they will make any difference in her life. She must accept things the way they are:

Six months now since she'd been sent away to London. Every morning she opened her eyes she thought, If I were the wishing type, I know what I would wish. And then 
she opened her eyes and saw Chanu's puffy face on the pillow next to her, (...) Was it cheating? To think, I know what I would wish? Was it not the same as making the wish? If she knew what the wish would be, then somewhere in her heart she had already made it (ALI, 2003, p. 9).

However, in a moment of anxiety, she prays, falls asleep and dreams of her sister Hasina in Bangladesh. The images of her dream are associated with nature, colors, affection and freedom, all elements that Brick Lane fails to give to her:

Silent. Nazneen fell asleep on the sofa. She looked out across jade-green rice fields and swam in the cool dark lake. She walked arm-in-arm to school with Hasina, and skipped part of the way and fell and they dusted their knees with their hands. (...) And heaven, which was above, was wide and empty and the land stretched out ahead and she could see to the very end of it, where the earth smudged the sky in a dark blue line (ALI, 2003, p. 13).

The distinction between Nazneen's past rural place of living and her urban environment in Brick Lane is made clear right from the beginning of the novel. Nazneen cannot find any joy in living in a place where the front doors "were all the same" (p.48). This passage in chapter 4 comes across as Nazneen's vision of her ideal home:

You can spread your soul over a paddy field, you can whisper to a mango tree, you can feel the earth beneath your toes and know that this is the place, the place where it begins and ends. But what can you tell to a pile of bricks? The bricks will not be moved (ALI, 2003, p. 86).

In the same chapter, there is a long description of Nazneen's walk around Brick Lane, in which we perceive her feeling of displacement. She ends up getting lost among 
the similar stoned buildings and starts to recite her favorite prayer. One of the verses says "Did He not find you an orphan and give you shelter?" (p.53). She might be feeling like an orphan due to her parents' absence but mainly because she misses her sister Hasina, who is her strongest link to home:

She had gotten herself lost because Hasina was lost. And only now did she realize how stupid she was. Hasina was in Dhaka. A woman on her own in the city, without a husband, without family, without friends, without protection. Hasina had written the letter before she left (p. 53).

Moreover, Nazneen develops an interest in watching ice-skating shows on TV, which help her forget the boredom of her routine as a housewife and make her feel pure as if she was part of a ritual that calmed her soul:

Life made its pattern around and beneath and through her. Nazneen cleaned and cooked and washed. (...) And the days were tolerable, and the evenings were nothing to complain about. Sometimes she switched on the television and flicked through the channels, looking for ice- skating. For a whole week it was on every afternoon while Nazneen sat cross-legged on the floor. While she sat, she was no longer a collection of the hopes, random thoughts, petty anxieties, and selfish wants that made her, but was whole and pure. The old Nazneen was sublimated and the new Nazneen was filled with white light, glory. But when it ended and she switched off the television, the old Nazneen returned (ALI, 2003, p. 34-35).

Through Nazneen's reading of her sister's letters, the reader gets to know that Hasina had run away to have a love marriage, this failed and led her to get involved with other men that only hurt her. Although Hasina goes through bad moments in Dhaka, she 
still has the strength and optimism to challenge her destiny and follow her heart. Thus, these letters often change Nazneen's sense of place in the world:

Whenever she got a letter from Hasina, for the next couple of days she imagined herself an independent woman too. The letters were long and detailed. Nazneen composed and recomposed her replies until the grammar was satisfactory, all errors expunged along with any vital signs. But Hasina kicked aside all such constraints: her letters were full of mistakes and bursting with life. Nazneen threaded herself between the words, allowed them to spool her across seven seas to Dhaka, where she worked alongside her sister. Raqib came as well. Sometimes, at the end of the day, she was surprised when Chanu arrived home. Then she made vows to herself. Regular prayer, regular housework, no more dreaming. She sent brisk, efficient letters to Hasina (p. 93-94).

Besides showing the distinction between Nazneen's impressions and experiences in London and those of Hasina in Bangladesh, the letters create fantasies of freedom for Nazneen, mainly when she feels trapped or confined in her flat. The letters, the flashbacks and the ice-skating on TV are all elements by which Nazneen gains mobility. She can only move from the walls and bricks that trap her in Brick Lane by using her imagination.

Another element that undermines Nazneen's mobility is the question of fate. Nazneen lives by the mantra, "What could not be changed must be borne. And since nothing could be changed, everything must be borne" (ALI, 2003, p. 5). She is torn between doing what she has been taught, which is accepting her fate and deciding on her own destiny. But when her first baby Raqib comes down with a serious illness, Nazneen struggles to keep her son alive as if she were willing to contradict her mother's indifferent acceptance of fate. 
However, after Raqib's death, the narrative is focused only on Hasina's letters. In chapter 7, we get to know about Nazneen through the words of her sister. Nazneen's story is no longer mediated by a narrator who foregrounds her point of view. On the level of action, Hasina's letters cover a period of eight years. During this period of time, the two sisters share deep feelings about their lives even though the narrative only shows Hasina's letters from Bangladesh. Despite Hasina's references to her sister's life in some sentences, it seems that this moment of the narrative is focused on the importance of Hasina's course of life for Nazneen: "You want to bring me to London. I like to come. But again this time your husband right and you must listen (...) Sister I know you enjoy to leave your flat. But I have come inside now. How I love the walls keep me here" (ALI, 2003, p. 174-181). In this passage, it is clear that while Nazneen feels the urge to experience some kind of mobility, Hasina feels safer inside her place. Both women are emotionally restless and share a sense of not belonging to where they are.

As the story unfolds, we see that Nazneen is going through a crisis between what she really is and what she appears to be. From the moment she takes up some sewing work to help bring money to the family and has an affair with the young Karim, Nazneen changes her focus and eventually realizes that her identity is fragmented. Although Karim tells her that she is "the real thing" (ALI, 2003, p. 419), she gradually becomes aware that even her lover has an idealized image of her.

By acting against the rules a village Muslim girl from Bangladesh would have to comply with, Nazneen transgresses the role of submissive South Asian wife, putting at risk her marriage and challenging old beliefs. Her previous link with her homeland, which was made through exchanging letters with Hasina, has given place to a more flexible idea of belonging. As her husband starts saving money to go back "home" though he has ignored 
Nazneen's pleas to visit her sister for years, she is not sure if going back will make her feel more protected and happy. Now that she knows that her sister Hasina is a prostitute in Bangladesh, she also wants to face facts of her life that cannot be avoided.

In the end, Nazneen manages to perceive that as she has gained autonomy to reject both her lover's proposal and her husband's idea to go back to Bangladesh, she has become able to find her place in the world. Her final decision to stay in London with her two daughters might be seen as a key element in the process of identification with the (no longer) strange land. Now that she has come to terms with her hybridity, there is no need to go far from Brick Lane through dreams or flashbacks. Finally, her house in Brick Lane and even London cease to be non-places as they become meaningful to her, with affective and significant bonds. The narrative of Brick Lane reveals the possibility to reflect on the inevitable identity fragmentation of subjects that, like Nazneen, live between two worlds.

\section{Referências}

ALI, Monica. Brick Lane. New York: Scribner, 2003.

AUGÉ, Marc. Não-lugares. Introdução a uma antropologia da supermodernidade. Tradução de Maria Lúcia Pereira. São Paulo: Papirus, 1994.

BAUMAN, Zygmunt. Modernidade líquida. Tradução de Plínio Dentzien. Rio de Janeiro: Jorge Zahar, 2001.

CLIFFORD, James. Diasporas. Cultural Anthropology, n. 9, v. 3, 1994, p. 302-338.

Recebido em 17 de abril de 2017.

Aceito em 18 de janeiro de 2018. 